\title{
URGENSI HUKUM KEPATUHAN SYARIAH DALAM PERBANKAN SYARIAH DI INDONESIA
}

\author{
Siti Rahmi Kasim \\ E-Mail : siti.rahmi.kasim@gmail.com \\ Mahasiswa Pascasarjana Program Studi Ekonomi Syariah IAIN Manado \\ Rosdalina Bukido \\ E-Mail : rosdalina.bukido@iain-manado.ac.id. \\ Fakultas Syariah IAIN Manado \\ Institut Agama Islam Negeri (IAIN) Manado
}

\begin{abstract}
Abstrak. Artikel tentang urgensi hukum kepatuhan syariah dalam perbankan syariah di Indonesia merupakan telaah terhadap sumber-sumber kepustakaan. Artikel ini membahasa tentang kepatuhan syariah sebagai sebuah conditiosine qua non untuk perbankan syariah. Juga tentang kerangka hukum kepatuhan syariah dalam perbankan syariah di Indonesia. Kerangka kerja dari kepatuhan syariah dalam perbankan syariah di Indonesia di atas menunjukkan beberapa poin yang menarik. Regulasi terhadap kepatuhan syariah tampak dengan jelas memberikan penekanan setidaknya kepada tiga aspek: karakteristik tertentu dari bank syariah dan bisnis perbankan syariah sebagaimana dinyatakan dalam definisi, persyaratan untuk pendaftaran untuk sebuah ijin, dan prinsipprinsip operasional dari sebuah bank. Gubernur Bank Indonesia bertanggung jawab atas ijin pendirian bank. Hal ini berbeda dengan misalnya, Malaysia, dimana otoritas untuk menyetujui sebuah perijinan dari sebuah institusi bank berada dalam tangan Menteri Keuangan melalui rekomendasi dari Bank Sentral. Di samping itu, jelas juga bahwa pengajuan untuk sebuah izin harus menyertakan pernyataan terkait tujuan dari bank untuk melakukan bisnis perbankan yang sesuai dengan prinsip-prinsip syariah dalam Anggaran Dasar/Anggaran Rumah Tangga dari berdirinya sebuah bank.
\end{abstract}

Kata kunci : urgensi hukum; kepatuhan syariah; perbankan syariah.

Abstract. Article about the urgency of sharia law compliance on sharia banking in Indonesia a review against available sources of literature \& nbsp; This article supposed to be about sharia compliance as a conditiosine qua non into banking. And it is also about a legal framework to sharia compliance on sharia banking in Indonesia. The framework on which of submission sharia oon shariah banking in Indonesia above express its strongest a couple of point what was interesting about it. The regulation on sharia compliance was clearly visible emphassies at least to three aspects : Certain characteristics of sharia bank and banking business sharia as stated in definition, the requirements for registration for a permit, and the principles of operational from a bank. Bank Indonesia Governor in charge of approval the establishment of a bank. These aspects were in contrast as contrasted with eg Malaysia, where authority to passed a licensing of an institution banks are in hand finance minister through recommendations from central bank. On top of that, clear that fillinf for a permission to include statement related to the purpose of a bank to carry on the banking business in according with sharia principles in the articles of aassociation / household budget of the establishment of a bank.

Key Words : Law Urgency, Sharia, Compliance ; Sharia Banking 


\section{Pendahuluan}

Sejak awal kelahirannya, perbankan syariah dilandasi dengan kehadiran dua gerakan renaissance Islam modern: neorevivalis dan modernis. Tujuan utama dari pendirian lembaga keuangan berlandaskan etika ini adalah tiada lain sebagai upaya kaum muslimin untuk mendasari segenap aspek kehidupan ekonominya berlandaskanAl-Qur'an dan As-Sunnah. ${ }^{1}$

Upaya awal penerapan system profit dan loss sharing tercatat di Pakistan dan Malaysia sekitar tahun 1940-an, yaitu adanya upaya mengelola dana jamaah haji secara nonkonvensional. Rintisan institusional lainnya adalah Islamic Rural Bank di desa Mit Ghamr pada tahun 1963 di Kairo, Mesir. ${ }^{2}$

Suatu hal yang patut juga dicatat adalah saat ini banyak nama besar dalam dunia keuangan internasional seperti Citibank, Jardine Flemming ANZ Chase Chemical Bank, Goldman Sach, dan lain-lain telah membuka cabang dab subsidiaries yang berdasarkan syariah. Dalam dunia pasar modal pun, Islamic fund kini ramai diperdagangkan, suatu hal yang mendorong singa pasar modal dunia Dow Jones untuk menerbitkan Islamic Dow Jones Index. Oleh karena itu, tak heran jika scharf, mantan direktur utama Bank Islamic Denmark yang Kristen itu, menyatakan bahwa Bank Islam adalah patner baru pembangunan. ${ }^{3}$

Setelah dua rintisan awal yang cukup sederhana itu, bank Islam tumbuh dengan sangat pesat. Sesuai dengan analisa Prof Khursid Ahmad dan laporan International Association of

\footnotetext{
${ }^{1}$ Muhammad Syafii Antonio, Bank Syariah Teori ke Praktik, Cet.I (Jakarta: Gema Insani, 2001), h.18.

${ }^{2}$ Muhammad Syafii Antonio, Bank Syariah Teori ke Praktik, h.18.

${ }^{3}$ Muhammad Syafii Antonio, Bank Syariah Teori ke Praktik, h.19.
}

Islamic Bank, hingga akhir 1999 tercatat lebih dari dua ratus lembaga keuangan Islam yang beroperasi di seluruh dunia, baik di Negara-nrgara berpendudukan muslim di Eropa, Australia maupun Amerika.

Berkembangnya bank-bank syariah di Negara-negara Islam berpengaruh ke Indonesia. Pada awal periode 1980-an, diskusi mengenai Bank Syariah sebagai pilar ekonomi Islam mulai dilakukan. Para tokoh yang terlibat dalam kajian tersebut adalah Karnaen A.Perwataatmadja,M. Dawan Rahardjo,A.M. Saefuddin,M. Amien Azis, dan lain-lain beberapa uji coba ini pada skala yang relatif terbatas telah diwujudkan. Diantaranya adalah Baitul Tamwil-Salman, Bandung, yang sempat tumbuh mengesankan. Di Jakarta juga dibentuk lembaga serupa dalam bentuk koperasi, yakni Koperasi Ridho Gusti. ${ }^{4}$

\section{URGENSI KERANGKA HUKUM KEPATUHAN SYARIAH DALAM PERBANKAN SYARIAH DI INDONESIA}

Salah satu permasalahan yang perlu dicatat seiring dengan perkembangan perbankan syariah (shariah compliance). Dibalik lajunya perkembangan perbankan syariah, masih terdapat banyak hal yang dapat diperdebatkan terkait dengan produk dan operasional bank dari perspektif syariah.

Keberatan terhadap terlalu terkonsentrasinya praktik perbankan syariah pada transaksi murabahah dalam produk-produk bank syariah telah menimbulkan pertanyaan filosofis yang mendasar terkait kearah manakah perbankan syariah akan dijadikan sebuah model institusi keuangan baru? Bagaimana hal itu akan mampu membedakannya dari perbankan konvensional jika sebagian besar

\footnotetext{
${ }^{4}$ Muhammad Syafii Antonio, Bank Syariah Teori ke Praktik, h.25.
} 
produk dalam penerapan/ implementasinya mirip dengan apa yang diterapkan pada produk yang berdasarkan pada suku bunga.

Diperkirakan terdapat sekitar 40\% Bank Pembiayaan Rakyat Syariah (BPRS) dan beberapa bank konvensional yang menawarkan bisnis perbankan Islam tidak mematuhi terhadap prosedur murabahah, karena mereka ditengarai mempraktikkan murabahah dengan cara yang mirip dengan skema konvensional. 5 Ketidakpatuhan ini juga diindikasikan oleh berbagai temuan yang dilakukan oleh Bank Sentral. ${ }^{6}$

Jika prosedur Syariah tidak diterapkam dengan baik, maka hal ini berarti bahwa skema yang dilakukan adalah melalui prosedur yang konvensional. Hal ini karena bank bertujuan untuk menghindari terjadinya pajak berganda/ double taxation (untuk kasus sebelum dihapusnya pajak ganda), atau mungkin karena alasan penghematan biaya operasional, yang sampai saat ini masih menjadi dalam perbankan syariah. Faktanya adalah bahwa hal ini adalah bukanlah skema murabahah yang murni, namun lebih mirip dengan skema peminjaman uang merujuk pada tingkat suku bunga tertentu. ${ }^{7}$

Ketiadaan atau kekurangan pada panduan Good Corporate Govermance (GCG) dalam perbankan syariah (Islam) menyebabkan kesulitan dalam pengukuran terhadap implementasi kepatuhan syariah (shariah

5 Sebagaimana dinyatakan oleh Deputy Gubernur Bank Indonesia, Aulia Pohan (Republika, March 30, 2004), in, Achmad Setiyaji, "Perbankan Syariah Kian Menjamur di Nusantara", Pikiran Rakyat, June 18, 2004. Juga, lihat, Bisnis Indonesia, 3 Februari,, 2004.

6 Sebagaimana dinyatakan oleh Deputy Gubernur Bank Indonesia, Maulana Ibrahim dan dikutip dalam Bisnis Indonesia, 12 Februari, 2004. h.68. compliance), khususnya terhadap operasional dari bisnis perbankan dan tidak semata-mata pada produk yang ditawarkan. ${ }^{8}$ Karakter dari perbankan Syariah (Islam) yang secara nyata berbeda dari perbankan konvensional memerlukan sebuah GCG yang khusus. Jika hal ini tidak bisa disediakan, maka perbankan syariah akan kehilangan karakternya yang paling mendasar/fundamental dan hal ini akan menimbulkan ketidakkejelasan target dan tujuan dimasa depan.

Hal ini menjadi bukti bahwa secara kuantitas, dibalik perkembangan perbankan Islam, terutama dari jumlah bank dan kantor cabang mereka, dan aset mereka secara keseluruhan, telah timbul permasalahan terhadap upaya unttuk

mengimplementasikan/menerapkan prinsip-prinsip syariah.

\section{KEPATUHAN SYARIAH SEBAGAI SEBUAH CONDITIOSINE QUA NON UNTUK PERBANKAN SYARIAH}

Kepatuhan Syariah (shariah compliance) diartikan sebagai "sebuah kondisi dimana seluruh aktivitas dari sebuah institusi keuangan sejalan dengan syariah" atau "kesepadanan dari keseluruhan aktivitas institusi keuangan Islam dengan Syariah Islamiyah sebagaimana yang telah dinyatakan oleh fatwa yang disepakati" atau "bersandarnya dari keseluruhan aktifitas dalam institusi keuangan Islam terhadap Syariah Islamiyah" Definisi ini menunjukkan bahwa kepatuhan syariah adalah sebuah kondisi dimana secara keseluruhan aspek dari perbankan syariah secara penuh melaksanakan kegiatan yang berdasarkan pada prinsip-prinsip syariah. Berlawanan dari kondisi ini, ketika produk dan aspek operasional dari perbankan

\footnotetext{
8 "Bank Syariah butuh GCG Khusus" dalam Ekonomi Syariah, pada, www.ekonomisyariah.org (Akses 25 Juni, 2006).
} 
tidaklah sesuai dengan prinsip-prinsip syariah, maka dinilai sebagai tidak taat atau tidak patuh terhadap syariah.

Kepatuhan syariah adalah salah satu di antara sekian banyak isu yang paling utama terkait perbankan syariah. Secara sekilas, kepatuhan syariah seolah-olah muncul menjadi sebuah beban tambahan bagi perbankan syariah. Mengapa demikian?. Karena disatu sisi, bank syariah menjadi objek dari pengawasan terhadap aspek kehatihatian perbankan (prudential supervisory), sebagaimana yang diterapkan terhadap bank konvensional. Sedangkan di sisi lain bank syariah juga menjadi objek yang dikenai pengawasan terhadap kepatuhan pada prinsipprinsip syariah. Kedua-duanya sama penting di mana kegagalan dalam penerapan salah satu dari keduanya akan sama-sama memiliki konsekuensi hukum. Kegagalan pada aspek yang kedua (shariah compliance) akan menimbulkan sebuah pertanyaan mendasar yang langsung terkait dengan legalitas sebuah bank dari sisi kesyariah-annya, apakah bank tersebut dapat dikatakan sebagai sebuah bank syariah ataukah sebaliknya. Hal ini dikarenakan, sebagaimana implikasi dari definsi tersebut, bahwa sebuah bank yang diidentifikasikan/dikategorikan sebagai bank syariah dalah karena di dalam bank tersebut penerapan dari prinsipprinsip syariah selalu dikawal, dipelihara dan dijamin, dan tidak sebaliknya.

$\begin{array}{ccc}\text { Meskipun } & \text { kepatuhan } & \text { syariah } \\ \text { secara hukum } & \text { diukur melalui }\end{array}$ keberadaan regulasi, yang mungkin berbeda antara satu negara dengan negara lain, namun dapat dikatakan bahwa ketidakpatuhan terhadap syariah secara umum akan berakibat pada dihentikannya beroperasinya bank tersebut.

Definsi yang telah disebut di atas juga memberikan implikasi makna bahwa kepatuhan syariah merupakan sebuah aspek legal/hukum yang secara inheren melekat dalam sebuah bisnis perbankan syariah atau perbankan kinvensional yang membuka layanan perbankan syariah (syariah window). Kepatuhan syariah adalah salah satu bagian yang tidak dapat dipisahkan dari perbankan syariah. Hal ini dikarenakan perbankan syariah, sejak awal perkembangannya, ditemukan modelnya dan dikembangkan sebagai satu perwujudan dari konsep Islam di bidang ekonomi, dan secara lebih khusus yang terkait dengan permasalahan keuangan. Ketidakpatuhan bank terhadap ajaran Islam adalah sama saja artinya dengan pencederaan atau pelanggaran bank tersebut terhadap berbagai karakter dasar mereka.

Setidaknya, ada beberapa alasan yang mendukung kesimpulan di atas sebagaimana akan dipaparkan berikut ini.

\section{Penamaan Bank Syariah dan Penerapan Prinsip-prinsip Islam}

Islam, oleh kaum Muslim, dianggap lebih dari sekedar sebuah "agama/religi" dan dalam hal ritualitas. Secara utuh, ia adalah "al-din", yakni seperangkat hukum yang diturunkan dari Qur'an dan Sunnah, dua buah sumber utama dalam ajaran Islam. ${ }^{9} \mathrm{Hal}$ ini meliputi seluruh aspek kehidupan bagi seorang Muslim, dan perbankan adalah satu di antara berbagai aspek yang ada dalam struktur bangunan Islam itu. Perbankan syariah adalah bagian dari hukum kontrak bisnis dalam Islam yang berada dalam wilayah fiqh al-mu'amalah. Kedudukan dari hal-hal yang terkait dengan keuangan Islam, h.70.

\footnotetext{
${ }^{9}$ Agus Triyanta, Hukum Perbankan Syariah,
} 
inter alia Perbankan syariah, di dalam struktur bangunan Islam, dapat ditunjukkan dalam bagan di bawah ini.

\section{Bagan :}

Perbankan Islam dalam Konteks

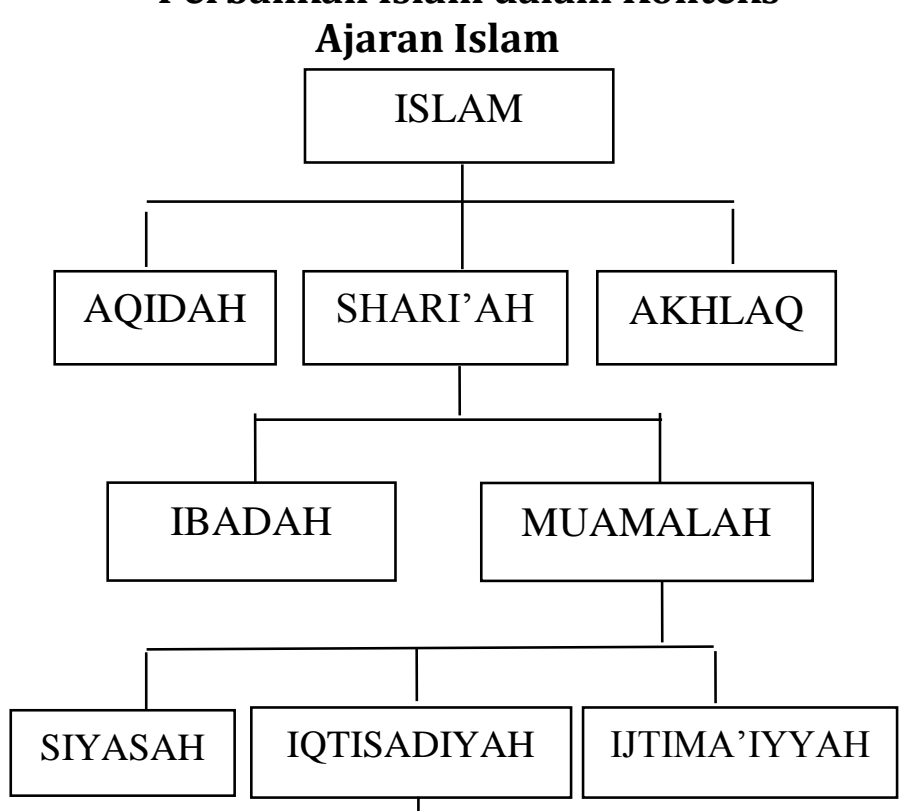

BANKING AND FNANCIAL ACTIVITIES

Islam terdiri atas tiga pilar utama; aqidah, syariah and akhlaq. Secara khusus, syariah adalah segala hal yang terkait dengan peraturan dalam tindakan berbagai tindakan dan aktivitas manusia. Aktivitas dalam konteks hubungan sesama manusia diklasifikasikan sebagai mu'amalah. Dikarenakan cakupan mu'amalah meliputi aktivitas politik, ekonomi dan social, maka menjadi jelaslah bahwa aktivitas keuangan dan perbankan juga berada dalam cakupan wilayah mu'amalah. Meskipun demikian, seluruh aspek dari berbagai aspek yang diklasifikasikan sebagai mu'amalah tidaklah dapat berdiri sendiri. Mereka saling berhubungan satu dengan yang lain. ${ }^{10}$

Bagan di atas juga menunjukkan bahwa perbankan syariah, disamping

${ }^{10}$ Agus Triyanta, Hukum Perbankan Syariah, h.71. menjadi jawaban atas tuntutan dan pencairan dari sementara orang terhadap sebuah bentuk bisnis keuangan yang lebih baik/lebih maju dari yang ada sekarang ini, perbankan syariah juga benar-benar telah menjadi jawaban terhadap tuntutan dari orang Islam untuk mematuhi aturan-aturan Islam secara totalitas, tidak parsial dalam bidang-bidang tertentu saja. Hubungan antara perbankan syariah dengan syariah Islamiyah juga menunjukkan secara jelas bahwa hal perbankan syariah ini adalah bagian dari mu'amalah iqtisodiyah (muamalah di bidang ekonomi), yang secara nyata diturunkan dari syariah sebagai induk aturan. Atas dasar alasan tersebut, pengembangan perbankan syariah, dari perspektif syariah, berarti juga sebuah upaya untuk menunaikan perintah syariah.

\section{Kepatuhan Syariah adalah Instrumen Penjamin Kesesuaian dengan Prinsip-Prinsip Syariah}

Dibandingkan dengan perbankan konvensional, yang telah beroperasi selama berabad-abad, perbankan syariah adalah sebuah bisnis keuangan yang unik. Keunikan dari perbankan syariah ditunjukkan dalam beberapa hal Khusus. Disingkirkannya penggunaan sistem bunga adalah hal yang paling mencolok. Kontrak keuangan dalam perbankan syariah, yang secara jelas akan muncul dalam pembahasanpembahasan berikut adalah dimaksudkan untuk menggunakan, inter alia, kontrak yang berdasar jual-beli serta kontrak yang berdasar pada pembagian kerugian dan keuntungan (loss and profit sharing), dimana hal itu menjadi sesuatu yang asing dalam perbankan konvensional. Dan lagi, semua aset dan bisnis yang terkait dengan perbankan syariah haruslah berada di dalam kategori halal, sebagaimana pula bahwa tujuan utama 
dari kontrak yang dilakukan tidaklah untuk suatu kepentingan yang melanggar ajaran Islam.

Meskipun perbankan syariah berbeda dari perbankan konvensional, tetapi tetaplah ia merupakan bagian dari institusi bisnis. Sebagai bagian dari sebuah institusi bisnis, maka perbankan syariah pun kemudian tidak asing dari karakteristik-karakteristik dasarnya, yakni untuk mendapatkan keuntungan yang maksimun. Untuk bisa survive, perbankan syariah dipaksa untuk bersaing dan memaksimalkan efisiensi untuk mencapai peningkatan keuntungan. Bank ini juga tidak dapat lepas dari terkena resiko. ${ }^{11}$ Sebagai sebuah lembaga intermediasi keuangan, maka ia juga tidak sepi dari ancaman kriminalitas dan penyalahgunaan oleh mereka yang secara illegal melakukan tindakan dengan tujuan untuk mengambil keuntungan dengan cara yang tidak benar (profit-taking). Untuk itulah, maka perbankan syariah harus memenuhi aspek prudential (kehatihatian). Sebab, jika tidak, maka bank tersebut dapat saja akan ditutup oleh otoritas yang berwenang.

Untuk itu, berbagai aspek kekhasan dari perbankan syariah sebagaimana yang telah disebutkan di atas, tidak dapat dipungkiri memerlukan perangkat hukum yang sejalan, yang dapat mengelola dan memelihara kekhasan yang dimaksud. Kepatuhan syariah adalah perangkat hukum yang mampu menjawab kebutuhan tersebut. Peraturan tentang kepatuhan syariah adalah sebuah keharusan bagi bisnis perbankan syariah. Urgensi dari perlunya operasional perbankan syariah untuk diletakkan di bawah otoritas regulasi dari kepatuhan syariah adalah suatu kemestian jika dilihat dari sudut pandang hukum. Regulasi ini adalah

${ }^{11}$ Agus Triyanta, Hukum Perbankan Syariah, h.73. satu-satunya regulasi yang didesain untuk menjaga agar proses operasional dan produk Perbankan Syariah tetap berada dalam koridor prinsip-prinsip Islam. Kegagalan untuk mewujudkan regulasi tentang kepatuhan syariah ini, berarti sama saja dengan membiarkan bank syariah selalu tetap melanggar prinsip-prinsip syariah.

Dari sinilah, dapat dipahami bahwa kualitas dari sebuah perbankan syariah ditentukan tidak hanya berdasarkan pada pemenuhan sejumlah persyaratan seperti, The Capital Adequacy Ratio (CAR), Financing to Deposit Ratio (FDR), Non Performed Financing (NPF), jumlah dari nasabah, dan perluasan kantor cabang. Namun, hal itu lebih ditentukan oleh berbagai parameter Syariah. ${ }^{12}$ Dengan demikian, selain dari keharusan untuk berhatihati, Bank Islam juga harus taat terhadap ketentuan-ketentuan ajaran Islam.

Hal ini, pada faktanya menunjukkan bahwa perbankan syariah terikat secara ketat oleh ikatan ganda (ikatan syariah dan sekaligus ikatan kehati-hatian perbankan) jika dibandingkan dengan institusi keuangan yang berdasarkan pada sistem bunga.

\section{Kepatuhan Syariah dan Inseminasi Etika Islam Bagi Seluruh Pihak yang Terlibat}

Dengan mempertimbangkan latar belakang sejarah perbankan syariah yang telah disebutkan di depan, adalah penting untuk mencatat bahwa nilai-nilai religius merupakan sebuah kekuatan pendorong (driving force) dari lahirnya perbankan Islam (syariah). Karenanya, dapat disimpulkan bahwa keseluruhan operasi dari sistem perbankan ini harus dilaksanakan

\footnotetext{
${ }^{12}$ Agus Triyanta, Hukum Perbankan Syariah, h.74.
} 
dalam sebuah kondisi tertentu di mana nilai-nilai Islam dan Etika Islam dapat diterapkan.

Terdapat beberapa nilai-nilai Islam yang secara mendasar dapat menjadi fondasi bagi aktivitas ekonomi dan bisnis. Perbankan syariah tidaklah merupakan aktivitas yang otonom, berbeda dari berbagai aktivitas bisnis keuangan Islam lainnya. Bisnis keuangan Islam berkorelasi/berhubungan sangat erat dengan ajaran Islam yang lainnya. Untuk itulah, arti penting penciptaan asmosfir yang bernuansakan Islam adalah suatu hal yang tidak dapat diragukan keharusannya bagi keberadaan perbankan syariah.

Terdapat berbagai aspek nilainilai yang menjadi sifat dasar dari etika Islam (akhaq al-karimah) yang sulit untuk diterapkan ke dalam sebuah bentuk regulasi yang bersifat mengikat, karena itulah tidak ada cara lain kecuali harus ditransplantasikan melalui sebuah perangkat kode etik yang berdasarkan nilai-nilai syariah yang kemudian dapat diterapkan, dan hal itu sekaligus menjadi bagian dari kepatuhan terhadap Syariah. Beberapa nilai-nilai Islam yang sudah banyak dikenal adalah: jujur (shiddiq), dapat dipercaya (amanah), cerdas/skilful (fathanah), dan menyampaikan kebaikan (tabligh). ${ }^{13}$ Penerapan dari nilai-nilai ini akan mendorong bisnis keuangan Islam ke tataran yang lebih tinggi dalam hal kesesuaian operasional perbankan syariah dengan apa yang dikehendaki oleh Islam.

Dari sudut pandang budaya korporasi, penerapan dari nilai-nilai adalah merupakan hal yang sangat vital bagi perbankan syariah. Budaya korporasi haruslah disusun dalam sebuah upaya tertentu dimana secara h.76.

\footnotetext{
${ }^{13}$ Agus Triyanta, Hukum Perbankan Syariah,
}

moral dan spiritual merefleksikan nilainilai Islam, sebagaimana yang dikatakan oleh Janahi, A.L. bahwa "Semua staf yang terkait dengan bank dan nasabah yang terkait dengan mereka haruslah dibentuk dan ditata secara Islami serta bertindak dalam sebuah kerangka kerja yang sesuai dengan formula Islam..."14

Terkait dengan masalah etika Islam dalam kegiatan perbankan syariah, Hussayn Hamid Hassan menyerukan sejumlah anjuran. Dua hal yang paling penting di antara berbagai anjuran tersebut adalah: 15

1) Dewan direktur dan para pekerja haruslah berperilaku sebagai praktisi pembelajar (the learning practitioners), dan sekaligus pembelajar praktisi (practicing learners), yang komitmen untuk selalu melakukan pendalaman terhadap pemahaman dari almuamalah al-syariah dan aspekaspek dasar bisnis yang terkait dengan keuangan.

2) Mempunyai inisiatif yang bagus dan pekerja keras, sebagaimana disebutkan dalam Al-Qur'an dengan kualitas al-qawiyy al-amin. Al-amin atau al-amanahh berarti bahwa komitmen terhadap ahkam alshari'ah (hukum syariah). Alquwwah berarti mempunyai pengetahuan atau ahli bidang yang ditanganinya.

Sebagai sebuah sistem perbankan yang "berbasis pada sistem keyakinan" (faith based), maka isu mengenai moral hazard adalah salah satu dari sekian hal serius yang harus diperhatikan dalam perbankan syariah. Karena itulah, nilai-nilai Islam yang

${ }^{14}$ A.L. Janahi dalam bukunya yang bertajuk, Islamic Banking, Concept and Future (Manama: Bahrain Islamic Bank, 1995), dikutip oleh: Lewis and Algaud, 165.

${ }^{15}$ Hussyn Hamid Hassan, Paper presented in al-Mu'tamar al-Thalith li al-Hai'at al-Shariyyah li al-Mu'assasat al-Maliyah al-Islamiyyah, 5-6 Oktober, 2003 in Bahrain, 7-8. 
telah disebutkan haruslah menjadi aturan main yang mengikat/bersifat keharusan dalam operasional perbankan syariah, dan anggota dewan direksi dari perbankan syariah dan demikian juga halnya dengan anggota dewan syariah haruslah senantiasa waspada terhadap isu moral hazards, dibandingkan dengan bank-bank yang berbasis system bunga.

\section{KERANGKA HUKUM KEPATUHAN SYARIAH DALAM PERBANKAN SYARIAH DI INDONESIA}

Sebagaimana pembahasan

tentang kerangka kepatuhan syariah dalam perbankan syariah meliputi tiga aspek, maka dalam bagian ini, tiga aspek yang sama akan dilakukan. Dimulai dengan peraturan yang terkait dengan kepatuhan syariah, selanjutnya pembahasan akan bergerak menuju kepada jenis-jenis kontrak yang berlaku dalam bisnis Perbankan Syariah, dan selanjutnya berbagai hal yang terkait dengan aspek fiqh yang terkait dengan bisnis Perbankan Syariah.

\section{Pengaturan kepatuhan syariah}

Dari diskusi pada pembahasan sebelumnya, tampak jelas bahwa dalam waktu yang cukup lama, belum terdapat Undang-undang khusus yang mengatur perbankan syariah di Indonesia, dan akhirnya, baru pada tahun 2008 Undang-undang yang dinantikan itu lahir. Ketiadaan dari Undang-undang tersebut dalam waktu cukup lama telah mengakibatkan konsekuensi hukum yang sangat jelas. Antara lain bahwa aturan terkait Perbankan Syariah di Indonesia tersebar dalam berbagai bentuk regulasi, dan bukannya ada satu aturan yang paling utama. Namun dengan telah lahirnya Undang-undang No.21 Tahun 2008 tentang Perbankan Syariah, maka sudah cukup kuatlah kerangka regulasi bagi Perbankan Syariah di Indonesia.
Disamping penganturan yang mendasar yang diberikan pertama kalinya oleh Undang-undang No.7 Tahun 1992 tentang Perbankan, pengaturan selanjutnya diberikan oleh Undang-undang No.10 Tahun 1998 tentang Perbankan yang merupakan amandemen dari Undang-undang No.7 Tahun 1992 tentang Perbankan, serta yang paling urgen adalah Undangundang yang lebih spesifik, ialah Undang-undang No.21 Tahun 2008 tentang Perbankan Syariah yang kemudian dilengkapi dengan berbagai aturan yang lebih detail dan terperinci dalam berbagai Peraturan Bank Indonesia. Dengan menggunakan kerangka hukum dari peraturan inilah maka beberapa aspek dari regulasi terhadap kepatuhan syariah akan dibahas dalam paparan berikut.

\section{Terminologi Bank Syariah}

Definisi/pengertian

dari

perbankan syariah yang terdapat dalam kerangka kerja hukum adalah hal yang sangat penting untuk melihat bagaimana hubungan antara bank dan prinsip-prinsip keuangan Islam. Define berlaku sebagai sebuah alat ukur untuk menentukan bilamanakah sebuah institusi layak dianggap merupakan sebuah bank Islam atau tidak atau sebuah bank yang melaksanakan bisnis perbankan syariah.

Jauh sebelum lahirnya Undangundang Perbankan Syariah, yakni Undang-undang No.21 Tahun 2008, adalah UU No.10 Tahun 1998 tentang Perbankan berperan sebagai sebuah kerangka hukum pengaturan yang utama dalam perbankan syariah. UU No.10 Tahun 1998, tidaklah memberikan rujukan secara terperinci mengenai definisi atau pengertian dari bank syariah. Alasan dari ketiadaan definisi tertentu tersebut dikarenakan di Indonesia, bank syariah merupakan bagian dari bank komersial. Dengan kata lain, bank komersial adalah 
meliputi bank konvensional maupun bank Islam (Syariah). Hal ini disebutkan dalam pasal (1) ayat (3) bahwa "Bank Umum adalah bank yang melaksanakan kegiatan usaha secara konvensional dan atau berdasarkan Prinsip Syariah yang dalam kegiatannya memberikan jasa dalam lalu lintas pembayaran."

\section{Persyaratan Perijinan}

Sebagaimana yang terjadi pada umumnya di berbagai Negara, dalam system perbankan syariah di Indonesia, otoritas yang memberikan ijin untuk berdirinya sebuah bank syariah yang baru atau sebuah Divisi Bank Syariah (Unit Usaha Syariah/UUS) baru dalam bank konvensional adalah di antara otoritas tertinggi yang dimiliki oleh Bank Sentral, ialah Bank Indonesia. Kewenangan ini merupakan salah satu posisi yang strategis bagi Bank Indonesia untuk melakukan pengontrolan, tidak saja hanya dalam kepentingan untuk mengatasi terlalu banyaknya pemain dalam industri perbankan (sebagaimana yang pernah terjadi di akhir masa Order Baru), namun yang lebih utama adalah dalam hal menjamin bhwa bank syariah serta Unit Usaha Syariah agar melakukan bisnis dan operasional yang patuh kepada prinsip-prinsip syariah. Dalam hal ini, adalah Gubernur Bank Sentral yang memegang otoritas/kewenangan untuk memberikan sebuah ijin, dan bukannya Menteri Keuangan sebagaimana yang berjalan di Negara tetangga, Malaysia.

Apa yang muncul dari Peraturan Bank Indonesia Peraturan Bank Indonesia Nomor 11/3/PBI/2009 Tentang Bank Umum Syariah (selanjutnya disebut sebagai PBI/2009) Kepada Semua Bank Umum Syariah Di Indonesia adalah bahwa aplikasi untuk persetujuan Prinsipil mensyaratkan bahwa surat permohonan yang harus didaftarkan oleh sedikit-dikitnya oleh seorang calon pemilik bank dan ditujukan kepada Gubernur Bank Indonesia, dengan menyertakan inter alia, draf pendirian, termasuk anggaran dasar (AD) dan anggaran rumah tangga (ART) dari perusahaan, dengan menyebutkan penunjukan dan tugas dari Dewan Pengawas Syariah (DPS).

Hanya setelah bank tersebut mendapatkan persetujuan secara prinsip, bank tersebut dimungkinkan untuk mengajukan perijinan secara lebih lanjut, yang dinamakan dengan ijin operasional. Aplikasi untuk ijin operasional haruslah memenuhi seperangkat persyaratan yang memerlukan hal-hal yang lebih valid. Jika aplikasi untuk persetujuan secara prinsip hanya mensyaratkan, semisal, draf naskah atau beberapa dokumen, dalam pengajuan ijin operasional di sini harus menyertakan bentuk asli dari sejumlah dokumen tersebut. Dengan demikian, akta pendirian dari suatu perusahaan dan juga memorandum anggaran dasar dan anggaran rumah tangga yang terkait haruslah secara asli dan dibuat secara resmi.

Sama halnya dengan persyaratan berdirinya suatu bank Islam, bank konvensional yang mengajukan permohonan untuk membuka unit Syariah atau divisi (yang memungkinkan mereka untuk menawarkan bisnis perbankan syariah) haruslah mengajukan permohonan yang disertai dengan seperangkat persyaratan.

\section{Operasi dari Bank}

Peraturan yang berlaku terkait perbankan syariah sebagaimana yang telah disebutkan terlebih dahulu, mengandung berbagai pengaturan yang dimaksudkan untuk memastikan agar keseluruhan operasional perbankan syariah selalu sejalan dengan prinsipprinsip Islam.

Dalam konteks operasional bank syariah atau divisi perbankan syariah, maka pemenuhan terhadap kepatuhan 
syariah adalah menjadi sebuah keharusan yang tidak dapat ditawar. Keharusan itu bukan hanya argument yang bersifat teoritis sebagaimana di atas, namun juga memiliki argument yuridis, sehingga dapat dikatakan bahwa bank diharuskan untuk menerapkan prinsip-prinsip syariah dan prinsip-prinsip kehatihatian/prudential dalam menjalankan bisnisnya secara pararel, dengan tidak megorbankan yang satu atas lainnya.

Lebih jelasnya, kedua aspek ini sama pentingnya sebagaimana keduanya juga merupakan persyaratan wajib dalam perbankan syariah. Sebagai konsekuensi selanjutnya, perbankan syariah tanpa prinsip-prinsip kehatihatian tentu saja tidak sempurna, dan ini pada gilirannya akan mengarahkan bank Islam menjadi sebuah institusi keuangan yang ekslusif yang sematamata hanya menyandarkan kepada sentiment agama untuk menarik nasabah-nasabah Muslim. Namun juga sebaliknya, sebuah bank syariah, bagaimanapun hati-hatinya, tanpa kepatuhan terhadap syariah adalah sama sebangun dengan perbankan yang berbasis bunga. Untuk alasan inilah, kedua elemen di atas sama pentingnya dalam seluruh produk dan operasinal dari bank.

Sebagaimana kepatuhan syariah adalah merupakan sebua kewajiban terhadap produk dan operasional perbankan syariah, hal ini tidak akan memiliki arti jika tidak diukur dan dipelihara melalui sebuah mekanisme yang jelas, dan sebuah badan yang bertanggung jawab terhadap pemeliharaan belumlah diatur atau belum dirancang. Dalam tujuan inilah, keberadaan (DPS) Dewan Pengawas Syariah adalah sebuah keharusan yang relevan.

Sebagaimana yang telah diketahui sebelumnya, perbankan syariah menerapkan suatu model bisnis perbankan yang rumit jika dibandingkan dengan model bisnis perbankan pada bank konvensional, sehingga pengawasan syariah pada perbankan Islam pun juga merupakan suatu hal yang rumit juga. Tugas pengawasan syariah ini membutuhkan tidak hanya sekedar kompetensi/kemampuan dari anggotaanggota dewan syariah serta staf dan pekerja yang paham terhadap ketentuan syariah, namun lebih dari itu memerlukan adanya sebuah kerangka hukum tentang kepatuhan syariah yang proporsional.

\section{Regulasi Terhadap Kontrak Muamalah dalam Bisnis Perbankan}

Jenis-jenis kontrak yang diterapkan dalam bisnis perbankan syariah di Indonesia, yang pertama dan terpenting adalah berdasarkan pada Undang-undang No.10 Tahun 1998. Deskripsi mendetail dari kontrakkontrak tersebut kemudian dibuat dalam Peraturan Bank Indonesia No.7/46/PBI/2005. Meskipun kemudian muncul Undang-undang No.21 Tahun 2008 tentang Perbankan Syariah, tetap saja ketentuan tentang akad dalam PBI tersebut merupakan ketentuan yang lebih mendetail dan menyajikan parameter yang lebih jelas dan aplikatif. Di sini, beberapa jenis kontrak dalam bisnis perbankan syariah di Indonesia disajikan. Setiap kontrak dalam pembahasan di bawah ini diamati dan dianalisis dengan menggunakan dasar dari pembahasan secara perspektif fiqh sebagaiman yang telah disampaikan ketika menganalisa berbagai aspek fiqh terkait dengan transaksi keuangan syariah.

\section{Wadi'ah}

Wadiah adalah penitipan dana atau barang dari pemilik dana atau barang pada penyimpan dana atau barang dengan kewajiban pihak yang menerima titipan untuk mengembalikan 
dana atau barang titipan sewaktuwaktu.

\section{Mudarabah}

Mudarabah adalah penanaman dana dari pemilik dana (shahibul maal) kepada pengelola dana (mudharib) untuk melakukan kegiatan usaha tertentu, dengan pembagian menggunakan metode bagi untung dan rugi (profit ana loss sharing) atau metode bagi pendapatan (revenue sharing) antara kedua belah pihak berdasarkan nisbah yang telah disepakati sebelumnya.

\section{Musyarakah}

Musyarakah adalah penanaman dana dari pemilik dana/modal untuk mencampurkan dana/modal mereka pada suatu usaha tertentu, dengan pembagian keuntungan berdasarkan nisbah yang telah disepakati sebelumnya, sedangkan kerugian ditanggung semua pemilik dana/modal berdasarkan bagian dana/modal masing-masing.

\section{Murabahah}

Murabahah adalah jual belibarang sebesar harga pokok barang ditambah dengan margin keuntungan yang disepakati.

\section{Ijarah}

Ijarah adalah transaksi sewa menyewa atas suatu barang dan atau upah mengupah atas suatu jasa dalam waktu tertentu melalui pembayaran sewa atau imbalan jasa.

Qard al-Hasan

"Qard" secara hukum berarti "pinjam meminjam dana tanpa imbalan dengan kewajiban pihak peminjam mengembalikan pokok pinjaman secara sekaligus atau cicilan dalam jangka waktu tertentu." Dalam layanan perbankan, kontrak ini diimplementasikan dalam bentuk pinjaman Qard al-Hasan, sifat dasarnya adalah untuk kebajikan.

\section{Istisna'}

Istisna' adalah jual beli barang dalam bentuk pemesanan pembuatan barang dengan criteria dan persyaratan tertentu yang disepakati dengan pembayaran sesuai dengan kesepakatan.

\section{Salam}

Salam adalah jual beli barang dengan cara pemesanan dengan syaratsyarat tertentu dan pembayaran tunai terlebih dahulu secara penuh.

\section{Kafalah}

Kafalah adalah jaminan yang diberikan oleh penanggung (kafiil) kepada pihak ketiga untuk memenuhi kewajiban pihak kedua atau yang ditanggung (makfuul 'anhu, ashil).

\section{Wakalah}

Wakalah adalah akad pelimpahan kekuasaan atau pemberian kuasa untuk hal-hal yang boleh diwakilkan dari satu pihak kepada pihak lain.

\section{Berbagai Isu yang Terkait Fiqih Dalam Kontrak Keuangan Syariah}

Meskipun praktik perbankan syariah telah berjalan sekitar 23 tahun di Indonesia, pangsa pasar/share dari bank-bank Syariah dibandingkan dengan aset perbankan nasional secara keseluruhan masih relative rendah. Hal ini tampaknya terkait dengan kenyataan bahwa berbagai permasalahan dihadapi di sepanjang perkembangakan perbankan syariah di negeri ini, yang tampaknya sangat jauh berbeda dengan apa yang terjadi di negara lain, misalnya Malaysia. Berbagai permasalahan yang muncul terkait secara erat dengan masalah-masalah fiqih, bukannya aspek operasional dari bank. Pembahasan di bawah ini adalah beberapa issu fiqih yang utama yang terkait dengan perbankan syariah di Indonesia. 


\section{Persepsi umat Islam Tentang Bunga}

Sekilas, isu terhadap suku bunga tampaknya tidak berhubungan langsung dengan kepatuhan syariah. Meskipun demikian, ketika isu ini dianalisa lebih lanjut, kesimpulannya adalah terjadi sebaliknya. Hal ini dikarenakan ketika suatu masyarakat mempersepsikan bahwa suku bunga dalam bank merupakan bentuk dari riba, kepatuhan syariah adalah menjadi sebuah isu yang penting. Atau bahkan konsep kepatuhan syariah menjadi runtuh. Sebaliknya, jika masyarakat tidak memandang bahwa suku bunga adalah riba, kepatuhan syariah menjadi kurang penting.

Bagi orang-orang Muslim di Indonesia, sebuah keputusan hukum yang kuat tentang pelangaran dari bunga bank dalam bank konvensional yang hal itu merupakan riba sangat diperlukan. Namun sayangnya, hal ini baru terjadi pada tahun 2004, yaitu ketika MUI (Majelis Ulama Indonesia) mendeklarasikan secara resmi keputusan yang telah dibuatnya, yakni No.1/2004 yang menyatakan bahwa suku bunga dianggap sebagai riba dan untuk itu dilarang dalam Islam.

Keputusan dari MUI tidaklah menyelesaikan semua permasalahan yang dihadapi oleh perbankan syariah di negeri ini, meskipun hal ini merupakan hal yang vital dalam meningkatkan kesadaran umat Islam terhadap pentingnya perbankan syariah. Hal ini terkait dengan setidaknya dua buah faktor; pengakuan terhadap fatwa, dan juga status dari MUI. Pengakuan terhadap fatwa masih lemah, dimana fatwa yang dikeluarkan tersebut tidaklah bersifat mengikat, bahkan terhadap umat Islam sekalipun. Tampaknya, bahwa pemerintah sendiri tidaklah terlalu dipengaruhi oleh dikeluarkannya fatwa semacam ini, hal itu dibuktikan dengan tidak munculnya kebijakan yang tegas sampai sejauh ini untuk memback-up fatwa tersebut. Hal ini terkait pada faktor kedua, berupa posisi dari MUI dalam system politik di Indonesia. Badan ini tidak lebih dari sekedar organisasi non-pemerintah dengan sebuah posisi khusus sebagai sebuah mitra dari pemerintah dan dengan demikian dia bukanlah merupakan badan atau lembaga pemerintahan.

Berbeda dari Negara-negara Islam lain dimana terdapat sebuah posisi yang jelas akan larangan terhadap riba yang telah diterima secara luas, di Indonesia masih mengalami permasalahan-permasalahan mendasar dalam hal ini.

Afialiasi "Madzhab" dalam Pengembangan Perbankan Syariah

Isu lain yang muncul sejalan dengan pengembangan perbankan syariah di Indonesia adalah pilihan antara mengadopsi tren yang ada; antara model Timur Tengah atau model Malaysia sebagai sebuah model dari perbankan syariah. Sebagaimana telah dibahas secara panjang lebar, model Timur Tengah menunjukkan dukungan kuat dan menjunjung tinggi pendapat dari jumhur ulama, meskipun dalam praktinya, hal ini lebih konservatif. Hal ini berbeda dari Malaysia, yang mana lebih inovatif dalam pengembangan berbagai produk dan jasa/layanan, meskipun itu menuai kritik terkait pandangan Malaysia terhadap bay' al'Inah dan bay' al-dayn.

\section{Akad Syariah dalam Bingkai Praktik Perbankan Konvensional}

Adanya inkonsistensi untuk menerapkan prinsip-prinsip Islam dalam bisnis perbankan adalah isu fiqh tersendiri dalam praktik perbankan syariah di Indonesia. Hal ini berarti bahwa meskipun perbankan syariah telah menyediakan berbagai produk pembiayaan dan penghimpunan dana yang secara nyata dan tegas disebutkan sebagai "berbasis pada prinsip-prinsip syariah," namun dalam penerapannya 
hal tersebut masih dipertanyakan. Sebagaimana kecenderungan umum dari bisnis perbankan adalah hanya untuk semata-mata keuntungan, permasalahan dari kebanyakan praktisi adalah masih terkungkung pada kerangka piker (mindset) perbankan konvensional (bank dengan berbasisi bunga).

Hal ini karena satu di antara faktor-faktor yang tersembunyi di balik konversi/perpindahan dari beberapa bank konvensional menjadi bank Islam adalah dikarenakan kasus kebangkrutan, dan bukannya dikarenakan keinginan yang tulus untuk menciptakan sebuah bisnis perbankan syariah yang sebenarnya. Dalam latar belakangnya, beberapa bank dikonversi karena bank-bank tersebut dilikuidasi, atau karena ketidakmampuan dari bank tersebut untuk berkompetisi di ranah bisnis perbankan konvensional. Bank syariah, yang merupakan bank Islam (berbendera penuh) kedua di negeri ini adalah merupakan konversi dari Bank Susila Bhakti yang mengalami problem keuangan setelah terjadinya krisis ekonomi.

\section{Kesimpulan}

Kerangka kerja dari kepatuhan syariah dalam perbankan syariah di Indonesia di atas menunjukkan beberapa poin yang menarik. Regulasi terhadap kepatuhan syariah tampak dengan jelas memberikan penekanan setidaknya kepada tiga aspek: karakteristik tertentu dari bank syariah dan bisnis perbankan syariah sebagaimana dinyatakan dalam definisi, persyaratan untuk pendaftaran untuk sebuah ijin, dan prinsip-prinsip operasional dari sebuah bank.

Gubernur Bank Indonesia bertanggung jawab atas ijin pendirian bank. Hal ini berbeda dengan misalnya, Malaysia, di mana otoritas untuk menyetujui sebuah perijinan dari sebuah institusi bank berada dalam tangan Menteri Keuangan melalui rekomendasi dari Bank Sentral. Di samping itu, jelas juga bahwa pengajuan untuk sebuah izin harus menyertakan pernyataan terkait tujuan dari bank untuk melakukan bisnis perbankan yang sesuai dengan prinsip-prinsip syariah dalam Anggaran Dasar/Anggaran Rumah Tangga dari berdirinya sebuah bank. Sebagai tambahan, Anggaran Dasar/Anggaran Rumah Tangga dari pendirian bank yang bersangkutan juga harus menyebutkan pembentukan badan/Dewan Penasehat Syariah, atau bahkan tidak hanya sekedar pembentukan, namun juga penegasan akan tugas-tugas dari badan tersebut.

Dalam aspek operasional dari bank, terdapat dua buah badan pengawas, yakni DPS (Dewan Pengawas Syariah) pada level industri (perbankan) dan DSN (Dewan Syariah Nasional) pada level nasional. Jika melihat berbagai Negara lain, dalam hal kelembagaan pengawasan ini ada sedikit berbeda.

Di dalam perbankan syariah, kontrak-kontrak Islam yang dapat diterapkan adalah sejalan/pararel dengan kontrak-kontrak sebagaimana dalam fiqh mu'amalah. Meskipun demikian, terdapat beberapa kontrak yang diterapkan dalam perbankan syariah di Indonesia yang belum didapatkan definisinya secara hukum, semisal hiwalah dan rahn. Dikarenakan belum ditetapkan secara legal, maka deskripsi terhadap batasan dan persyaratan terkait terhadap kontrak semacam ini berada di tangan DSN dan BPS. Dari pengamatan terhadap berbagai definisi legal dari beberapa kontrak yang telah disebutkan di atas, tampak jelas bahwa definisi/pengertiannya terkadang tidaklah sesederhana sebagaimana yang seharusnya disajikan dalam sebuah 
definisi legal/hukum. Terdapat beberapa pengertian yang masih terlalu luas dan perlu diperjelas (lebih spesifik), Ijarah, misalnya sebagai salah satu contoh.

\section{DAFTAR PUSTAKA}

Antonio, Muhammad Syafii, 2001, Bank Syariah Teori ke Praktik, Cet.I (Jakarta: Gema Insani).

Triyanta, Agus, Hukum Perbankan Syariah, (Malang: Setara Press)

Janahi, A.L. dalam bukunya yang bertajuk, Islamic Banking, Concept and Future (Manama: Bahrain Islamic Bank, 1995), dikutip oleh: Lewis and Algaud
Hassan, Hussyn Hamid, Paper presented in al-Mu'tamar al-Thalith li al-Hai'at al-Shariyyah li al-Mu'assasat alMaliyah al-Islamiyyah, 5-6 Oktober , 2003 in Bahrain

Pohan, Aulia, (Republika, March 30, 2004), in, Achmad Setiyaji, "Perbankan Syariah Kian Menjamur di Nusantara", Pikiran Rakyat, June 18, 2004. Juga, lihat, Bisnis Indonesia, 3 Februari,, 2004.

Deputy Gubernur Bank Indonesia, Maulana Ibrahim dan dikutip dalam Bisnis Indonesia, 12 Februari, 2004.

"Bank Syariah butuh GCG Khusus" dalam Ekonomi Syariah, pada, www.ekonomisyariah.org (Akses 25 Juni, 2006). 